\title{
Symptomatology and Pathology of Strawberry Diseases Causing Leaf Blight and Fruit Rot in Punjab
}

\author{
S. K. Thind", Simranjit Kaur and Ishwinder Kamboj \\ Department of Plant Pathology, PAU, Ludhiana-141004 (Punjab) India \\ *Corresponding author
}

\section{A B S T R A C T}

\begin{tabular}{l} 
K e y w o r d s \\
$\begin{array}{l}\text { Strawberry } \\
\text { anthracnose, } \\
\text { Colletotrichum } \\
\text { gloeosporioides, } \\
\text { Symptomatology, } \\
\text { Pathology }\end{array}$ \\
\hline Article Info \\
$\begin{array}{l}\text { Accepted: } \\
\text { 25 June } 2020 \\
\text { Available Online: } \\
\text { 10 July } 2020\end{array}$ \\
\hline
\end{tabular}

The present investigations were carried out in the Plant Pathology Laboratory of Department of Fruit Science, Punjab Agricultural University, Ludhiana from 2014 to 2016. The anthracnose disease produce brown to pin head black necrotic lesions on tip and margin of leaves, brown to tan sunken circular spots with minute stroma in centre of lesion on green fruits and dark brown to black water soaked lesion causing browning and rotting of ripe fruit The Rhizopus rot infection start on ripe fruit with secretion of red juice from fruit tissue which later covered with white fuzzy mycelium. For pathogenecity test, pin prick method of inoculation on leaves, green fruit and ripe fruit was found better than spray method. On the basis cultural and morphological characteristics and identification report of Indian Type Culture Collection (ITCC), Division of Plant Pathology, Indian Agricultural Research Institute, New Delhi, the causal agent of production of anthracnose type symptom was identified as Colletotrichum gloeosporioides. Acervuli are not produced in culture but on plant tissues with black and erect setae. A temperature of $25^{\circ} \mathrm{C}$ found significantly effective in favoring the mycelial growth and below $15^{\circ} \mathrm{C}$ failed to support the growth of the pathogen. Significantly highest sporulation occurred in 15 days old culture of the pathogen. The spore germination was found significantly better at $25^{\circ} \mathrm{C}$ after 4 hours of incubation and cent per cent after 16 hours of incubation.

\section{Introduction}

Strawberries (Fragaria ananassa Duch) are grown in subtropical and temperate countries. In India, it is cultivated in Haryana, Mizoram, Meghalaya, Kerala, Himachal Pradesh, Madhya Pradesh, Uttar Pradesh, Tamil Nadu, Jammu and Kashmir, Maharashtra, West Bengal, Delhi, Punjab and Rajasthan, Jammu \& Kashmir and Nilgiri hills covering an area of 0.83 thousand hectares with production of 8.42 MT fresh fruit (Anonymous, 2015).
Strawberry is rich source of vitamin C and iron and some varieties having high flavour with bright red colour are also suitable for processing particularly of making icecream. Strawberry plants are vulnerable to various biotic and abiotic factors. Among these, anthracnose disease is economically important causing 60-75 per cent losses of marketable fruit (Legard and Mackenzic, 2003; Smith, 2008). Serious epidemics occurred in the United States under warm and humid weather conditions causing more than 
30 per cent losses (Howard et al 1992). A number of farmers are cultivating strawberry in Punjab due to its high economic return. The incidence of the disease varied from 6-28 per cent in Punjab causing huge fruit rot losses (Kaur et al., 2016). Keeping in view the destructive nature of the disease in Punjab, an attempt has been to create awareness among the scientists and farmers about the symptomatology and causal agent of the disease for devising the strategies for its effective management.

\section{Materials and Methods}

The present investigations were carried out in the Plant Pathology Laboratory of Department of Fruit Science and old orchard of Punjab Agricultural University, Ludhiana during the year 2014 to 2016.

\section{Disease symptom and collection of diseased samples}

Strawberry growing areas in different districts of Punjab, viz. Barnala, Gurdaspur, Hoshiarpur, Ludhiana, Patiala and Ropar were surveyed from January to March for two consecutive years 2015 and 2016 to record the symptom expression on strawberry varieties, Camarosa, Chandler and Sweet Charlie. The observations on the development of strawberry anthracnose and other diseases were recorded on leaves, green fruits and mature fruits. Samples of diseased crown, leaves and fruits were collected in perforated polythene bags and brought to the laboratory for isolation studies.

\section{Isolation and raising of pure culture of the pathogen}

Isolation of the causal agent was carried out from the diseased crown, leaves and fruits portion of the strawberry plants. Small bits ( 5 x $5 \mathrm{~mm}$ size) were cut and surface sterilized with 0.1 per cent mercuric chloride for one minute followed by four washings with sterile distilled water. The bits were then transferred to Potato Dextrose Agar (PDA) slants under sterile conditions and incubated at $25 \pm 1^{\circ} \mathrm{C}$. The culture of fungus was purified by single spore isolation technique.

\section{Pathogenecity test}

A large number of artificial inoculations were carried out on leaves, green fruit and mature fruits of variety Chandlerr of strawberry by pin prick and spray methods. The samples of uniform size and age were collected and surface sterilized. In pin prick method, the tip of sterilized pin was tapped lightly on 15 days old mycelium and then leaves, green fruit and mature fruits surface was pricked. In spray method, $2 \times 10^{6}$ spores $/ \mathrm{ml}$ inoculum was prepared and sprayed over marked surface of leaves, green fruit and mature fruits. Five sites were inoculated on each leaf, green fruit and mature fruit and placed in moist chamber at $25 \pm 1{ }^{\circ} \mathrm{C}$. The observations on number and size of lesions and time required for the development of anthracnose symptoms were regularly recorded.

\section{Characteristics of the pathogen}

The morphological and cultural characters of the fungus were observed from the culture obtained from diseased sample. The colony characters of fungus were recorded till 15 days of incubation starting from the day fungus start producing mycelium. The culture harvested after pathogenecity test was compared with original culture under laboratory conditions and was further sent to Indian Type Culture Collection (ITCC), Division of Plant Pathology, Indian Agricultural Research, New Delhi for identification to confirm the identity of the pathogen causing strawberry anthracnose disease. 
Effect of temperature on development of pathogen under controlled conditions

\section{Effect on radial growth of fungal mycelium}

To determine the minimum and maximum range of temperature for the linear growth of the $C$. gloeosporioides, the pathogen was inoculated on PDA in Petri plates and incubated at $5^{\circ} \mathrm{C}, 10^{\circ} \mathrm{C}, 15^{\circ} \mathrm{C}, 20^{\circ} \mathrm{C}, 25^{\circ} \mathrm{C}$ and $30^{\circ} \mathrm{C}$ temperature. Five replications per treatment were kept. The linear growth of the fungus was measured at $24 \mathrm{hrs}$ intervals up to 9 days of incubation at different temperatures. The effect of "temperature" and "colony diameter" were analysed by completely randomized design in ANOVA $(\mathrm{p}=0.05)$ using CPCS-I software.

\section{Effect on extent of sporulation}

The cultures of $C$. gloeosporioides grown on PDA were used for sporulation studies after 15 days of incubation at temperatures of viz. $5^{\circ} \mathrm{C}, 10^{\circ} \mathrm{C}, 15^{\circ} \mathrm{C}, 20^{\circ} \mathrm{C}, 25^{\circ} \mathrm{C}$ and $30^{\circ} \mathrm{C}$. Spore suspension of each isolate was obtained by eluding five mycelia discs ( $5 \mathrm{~mm}$ size) of active culture in $5 \mathrm{ml}$ of FAA (formaldehyde: absolute alcohol: glacial acetic acid: water 2: 10: $1: 7)$ contained in capped glass vials. Five vials were used for each isolate. The sporulation in each isolate was measured with the help of haemocytometer. The effect of "temperature" on "sporulation potential" was analysed by completely randomized design in ANOVA $(p=0.05)$ using CPCS-I software.

\section{Effect on spore germination}

To determine the suitable temperature for maximum spore germination of $C$. gloeosporioides, different temperatures viz. $5^{\circ} \mathrm{C}, 10^{\circ} \mathrm{C}, 15^{\circ} \mathrm{C}, 20^{\circ} \mathrm{C}, 25^{\circ} \mathrm{C}$ and $30^{\circ} \mathrm{C}$ were tested. The spore suspension was prepared in 2 per cent dextrose solution. The cavity slides with hanging drops of spore suspension placed on cover slips were kept in Petri plates and after creating moist chambers these were incubated at different temperatures in different BOD incubators and the data on spore germination was recorded at $4,8,12$, 16, 20 and $24 \mathrm{hrs}$ of intervals. Five replications for each temperature were kept keeping single unit per replication. The effect of "temperatures" and "time interval" and their interaction on per cent spore germination were analyzed by two-way ANOVA $(\mathrm{p}=0.05)$ using CPCS-1 software.

\section{Results and Discussion}

During the surveillance of different strawberry grown area of Punjab, the following type of symptom expression on leaves, green fruit and mature fruit were observed from January to March months.

\section{Expression of anthracnose symptom}

\section{Symptom on leaves}

Necrotic lesions on tip and margins of leaves were observed (Plate 1). These lesions are earlier pin head sized and dark brown to black in color and later on expand $(5-6 \mathrm{~mm})$ to cover large area and become sunken straw and ashy colored in center with dark brown margins. Creamy spore mass is also produced in center of lesions (Plate 2).

Light concentric rings are sometimes present or absent inside the lesions. Under microscopic examination, dark colored setae are also visible in these lesions. The observations were in conformity with Vidhyalakshmi and Divya (2013) and Heidenreich and Truechek (2013) who also reported similar symptom production by anthracnose fungus. Jefferies et al (1990) also observed the production of slimy spore mass on the lesions in later stages of disease development. 
Table.1 Pathogenecity of C. gloeosporioides on strawberry plant parts

\begin{tabular}{|l|l|c|c|c|c|}
\hline $\begin{array}{c}\text { Method of } \\
\text { inoculation }\end{array}$ & \multicolumn{1}{|c|}{ Plant parts } & $\begin{array}{c}\text { Incubation periods } \\
\text { (days) }\end{array}$ & $\begin{array}{c}\text { No. of lesions } \\
\text { developed }\end{array}$ & $\begin{array}{c}\text { Per cent lesions } \\
\text { formed }\end{array}$ & $\begin{array}{c}\text { Average lesion size } \\
(\mathbf{m m})^{*}\end{array}$ \\
\hline \multirow{2}{*}{ Spray } & Leaves & 5 & 2 & 40.0 & 5.2 \\
\cline { 2 - 6 } & Green fruit & 6 & 2 & 40.0 & 5.7 \\
\cline { 2 - 6 } & Mature fruit & 3 & 4 & 60.0 & 7.0 \\
\hline \multirow{3}{*}{ Pin Prick } & Leaves & 4 & 4 & 80.0 & 6.0 \\
\cline { 2 - 6 } & Green fruit & 5 & 3 & 60.0 & 6.2 \\
\cline { 2 - 6 } & Mature fruit & 3 & 5 & 100.0 & 8.5 \\
\hline
\end{tabular}

*Observation after 10 days of inoculation, No. of sites inoculated $=5$

Table.2 Effect of temperature regimes on mycelial growth of $C$. gloeosporioides

\begin{tabular}{|c|c|c|c|c|c|c|c|c|c|}
\hline Temperature $\left({ }^{\circ} \mathbf{C}\right)$ & \multicolumn{8}{|c|}{ Mycelial growth $\left(\mathbf{c m}^{*}\right)$} \\
\cline { 2 - 12 } & \multicolumn{9}{|c|}{ Incubation (hours) } \\
\hline & $\mathbf{2 4}$ & $\mathbf{4 8}$ & $\mathbf{7 2}$ & $\mathbf{9 6}$ & $\mathbf{1 2 0}$ & $\mathbf{1 4 4}$ & $\mathbf{1 6 8}$ & $\mathbf{1 9 2}$ & $\mathbf{2 1 6}$ \\
\hline $\mathbf{5}$ & 0.0 & 0.0 & 0.0 & 0.0 & 0.0 & 0.0 & 0.0 & 0.0 & 0.0 \\
\hline $\mathbf{1 5}$ & 0.26 & 0.77 & 1.27 & 1.77 & 2.27 & 2.77 & 3.27 & 3.77 & 4.27 \\
\hline $\mathbf{2 0}$ & 0.54 & 1.14 & 1.74 & 2.34 & 2.94 & 3.54 & 4.14 & 4.74 & 5.34 \\
\hline $\mathbf{2 5}$ & 1.24 & 2.30 & 3.26 & 4.32 & 5.37 & 6.38 & 7.38 & 8.25 & 8.92 \\
\hline $\mathbf{3 0}$ & 1.20 & 2.00 & 2.80 & 3.60 & 4.40 & 5.20 & 6.00 & 6.80 & 7.60 \\
\hline
\end{tabular}

C.D. $(\mathrm{p}=\mathbf{0 . 0 5})$ Temperature $=0.65$, Hours $=0.88$, Temperature $\times$ Hours $=0.20$

* Observations based on average of five replications

Table.3 Effect of temperature regimes on sporulation of C. gloeosporioides

\begin{tabular}{|c|c|}
\hline Temperature $\left({ }^{\circ} \mathbf{C}\right)$ & Sporulation $\left(\times \mathbf{1 0}^{\mathbf{4}}\right.$ spores $\left./ \mathbf{m l}\right)$ \\
\hline $\mathbf{5}$ & 0.0 \\
\hline $\mathbf{1 5}$ & 16.4 \\
\hline $\mathbf{2 5}$ & 24.4 \\
\hline $\mathbf{3 0}$ & 32.2 \\
\hline Mean & 27.0 \\
\hline C. $\mathbf{D}$. $(\mathbf{p}=\mathbf{0 . 0 5})$ & 19.4 \\
\hline
\end{tabular}

Table.4 Effect of temperature regimes on spore germination of C. gloeosporioides

\begin{tabular}{|c|c|c|c|c|c|c|}
\hline \multirow{3}{*}{$\begin{array}{c}\text { Temperature } \\
\left({ }^{\circ} \mathbf{C}\right)\end{array}$} & \multicolumn{6}{|c|}{ Per cent spore germination } \\
\hline & \multicolumn{6}{|c|}{ Incubation (hours) } \\
\hline & 4 & 8 & 12 & 16 & 20 & 24 \\
\hline 5 & $0.0(0.0)$ & $0.0(0.0)$ & $0.0(0.0)$ & $0.0(0.0)$ & $0.0(0.0)$ & $0.0(0.0)$ \\
\hline 15 & $0.0(0.0)$ & $0.0(0.0)$ & $0.0(0.0)$ & $9.23(17.7)$ & $19.3(26.02)$ & $40.2(39.3)$ \\
\hline 20 & $0.0(0.0)$ & $12(20.3)$ & $41.1(39.9)$ & $61.4(51.6)$ & $71.1(57.5)$ & $80.7(64)$ \\
\hline 25 & $22.4(28.3)$ & $51.8(46)$ & $93.7(75.5)$ & $100(89.9)$ & $100(89.9)$ & $100(89.9)$ \\
\hline 30 & $0.0(0.0)$ & $49.3(44.6)$ & $82(64.9)$ & $100(89.9)$ & $100(89.9)$ & $100(89.9)$ \\
\hline
\end{tabular}

Values in parenthesis are arc sine transformed 


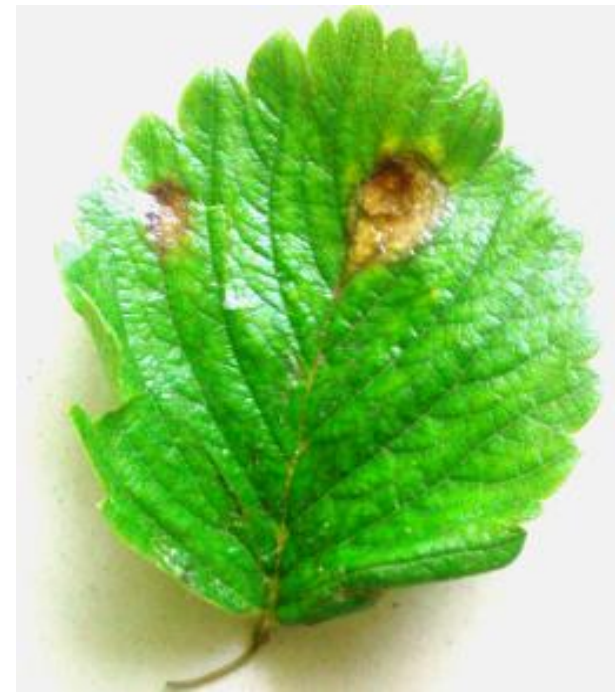

Plate1. Dark brown depresssed lesions

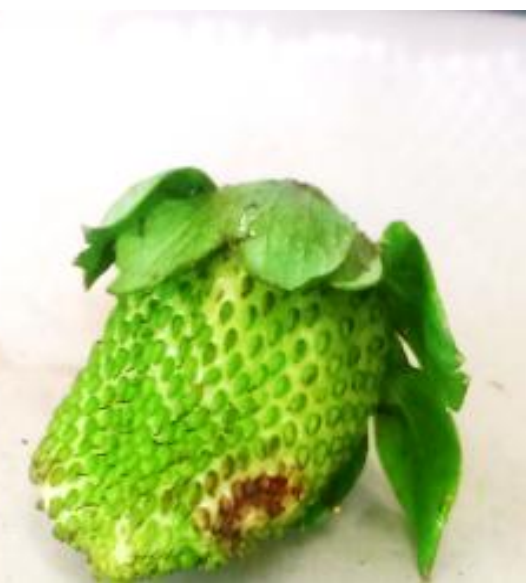

Plate 3. Anthracnose lesion on green fruit

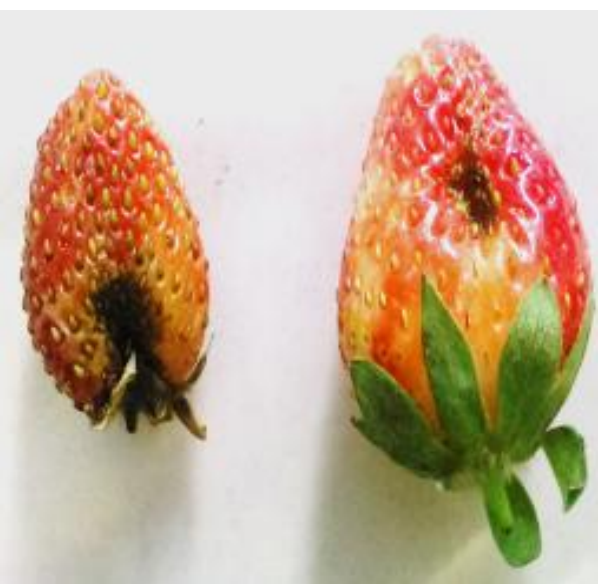

Plate 5. Anthracnose lesion on mature fruit

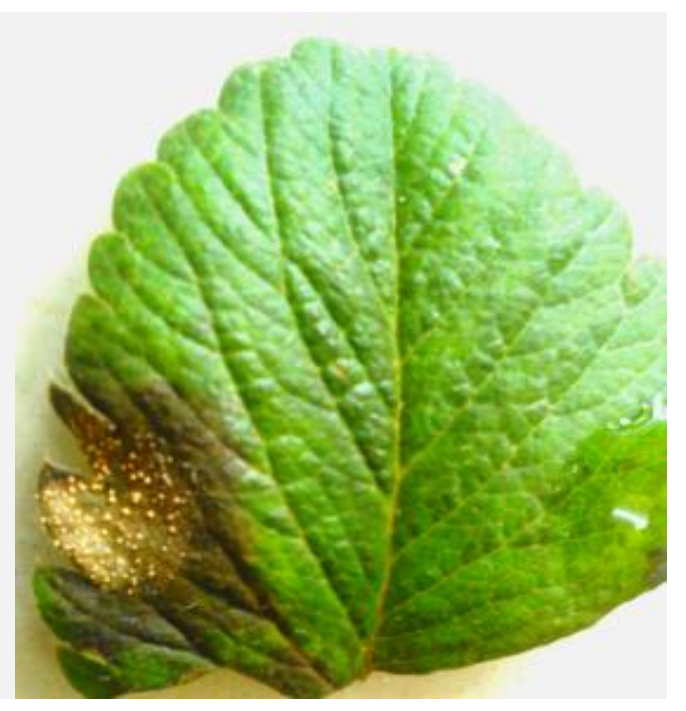

Plate 2. Creamy spore mass in centre of lesions

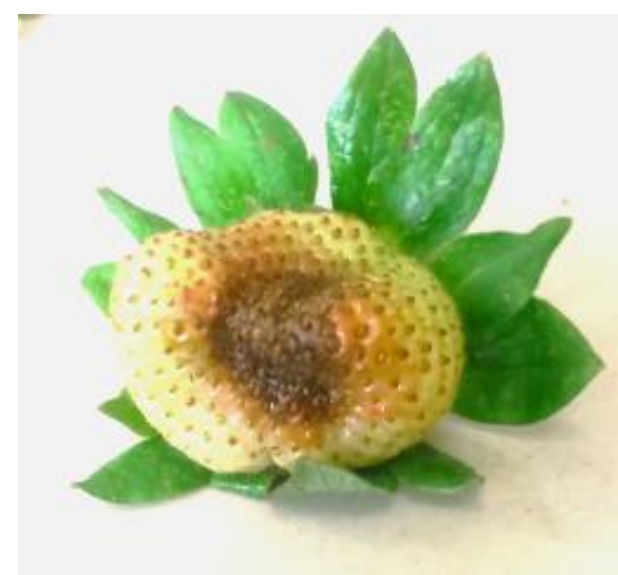

Plate 4. Increase in lesion size on fruit

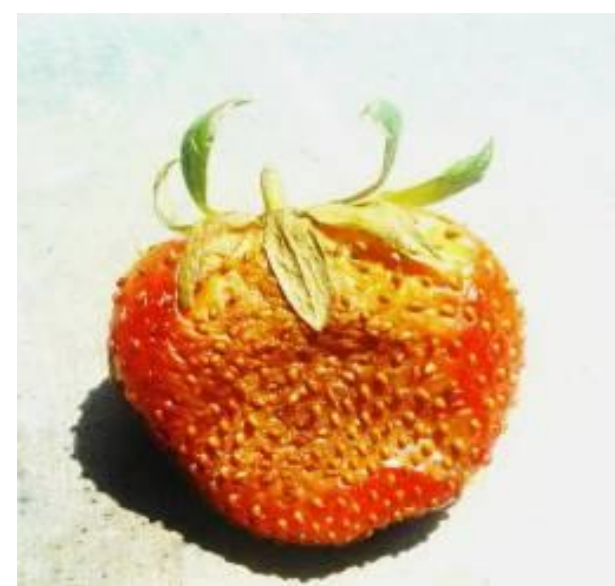

Plate 6. Lesion causing rotting of fruit in later stages 


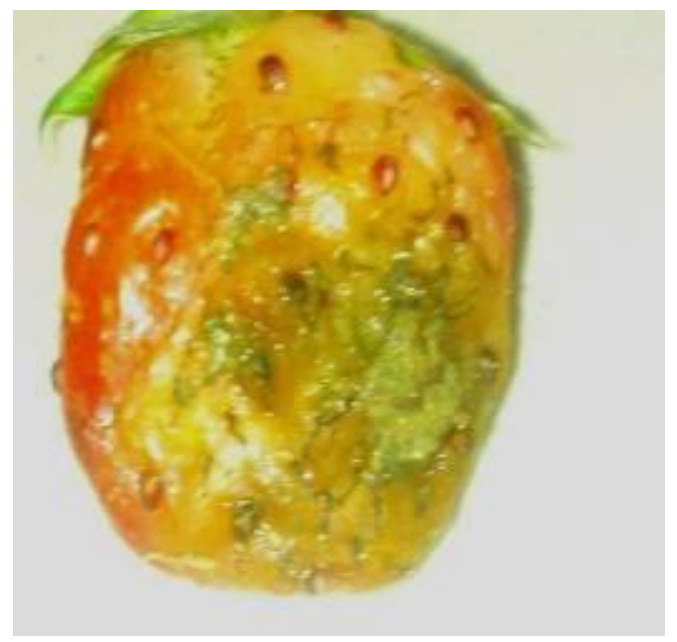

Plate7. Rhizopus rot on mature fruit

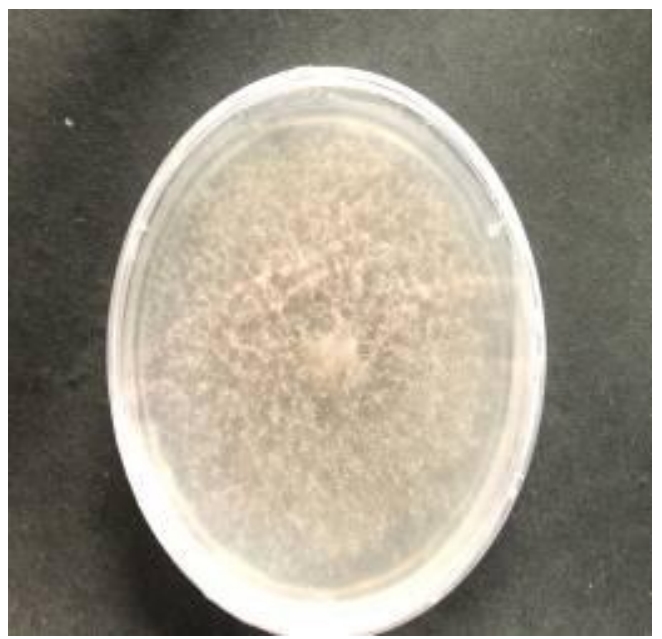

Plate 9.Grey colonies of $C$. gloeosporioides

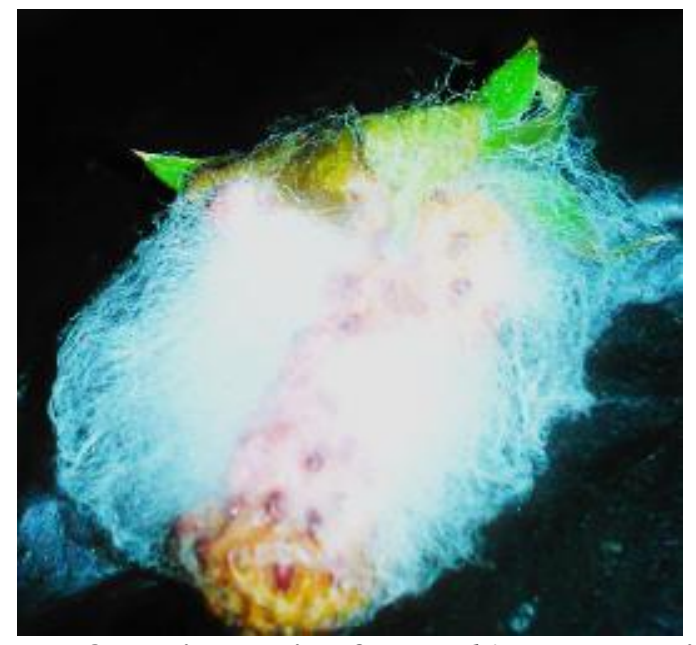

Plate 8. Fruit showing fuzzy Rhizopus mycelium

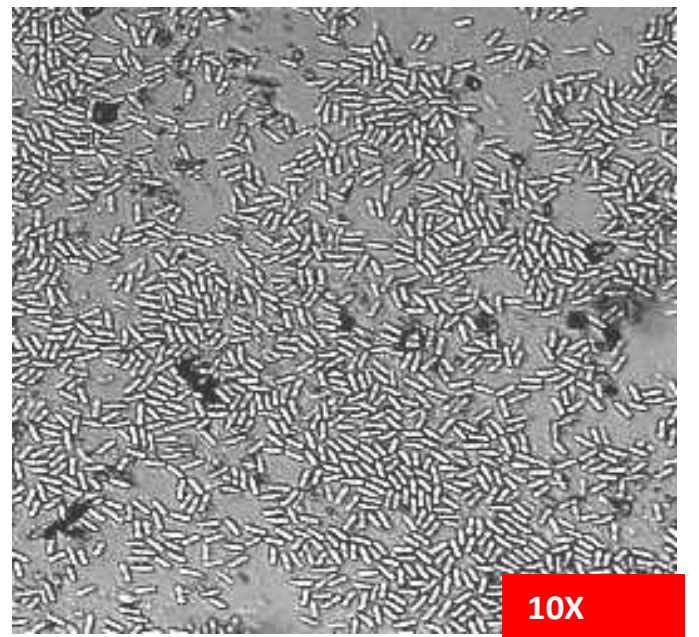

Plate 10. Shape and size of conidia

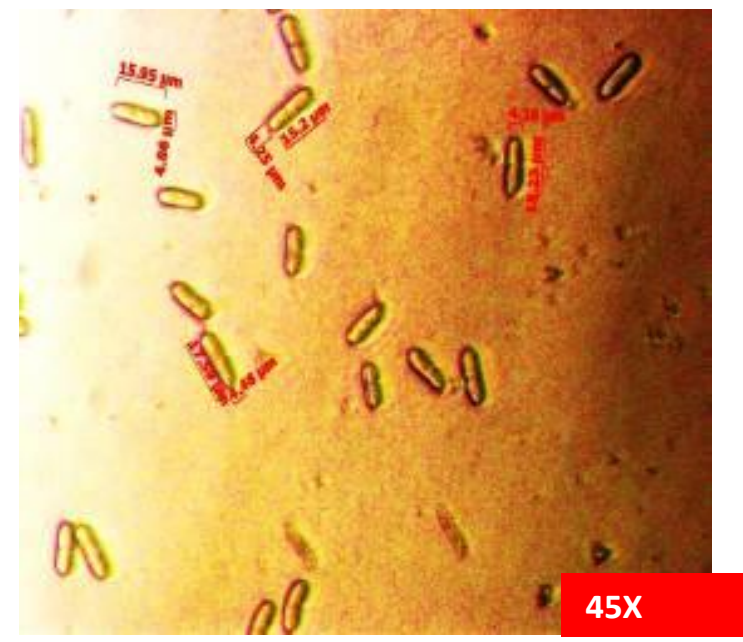

Plate 11. Shape and size of conidia

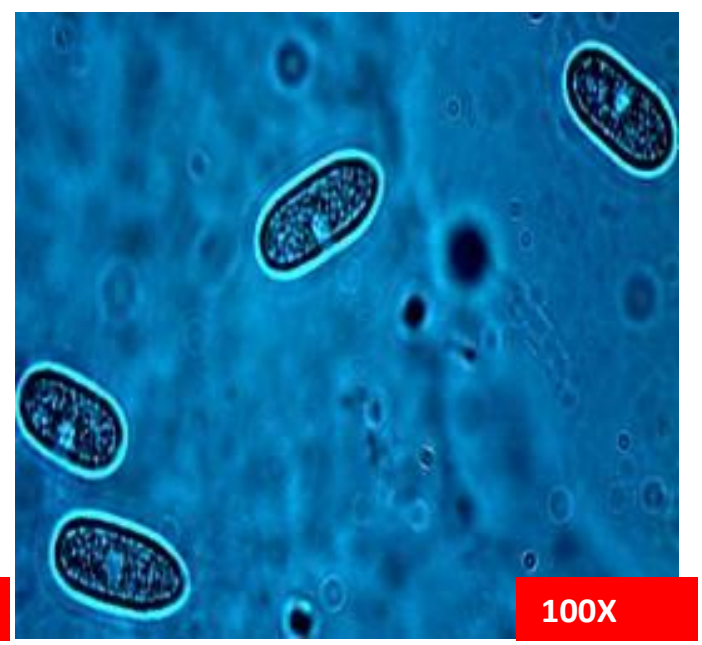

Plate 12. Shape and size of conidia 

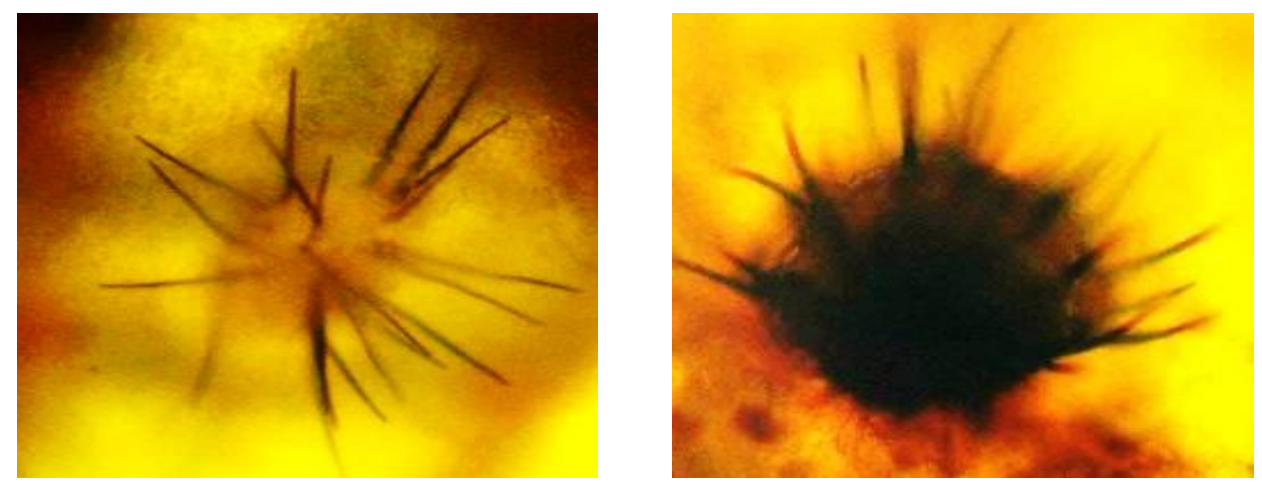

Plate $13 \&$ 14. Acervulli and setae development on leaf tissues
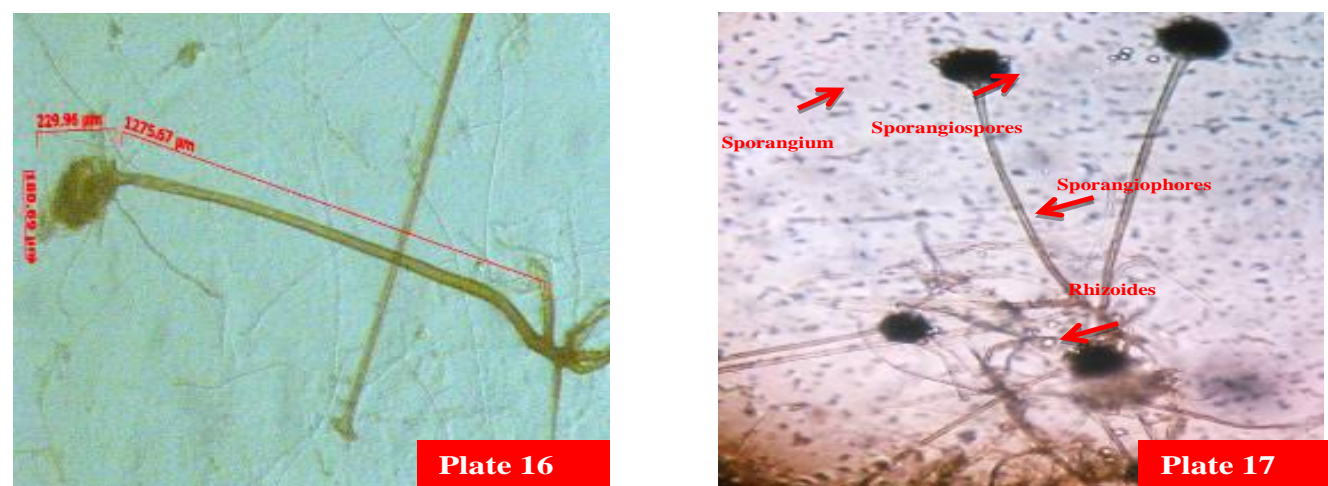

Plate 15\& 16. Microscopic view of Rhizopus showing rhizoides, sporangia and sporangiospore.

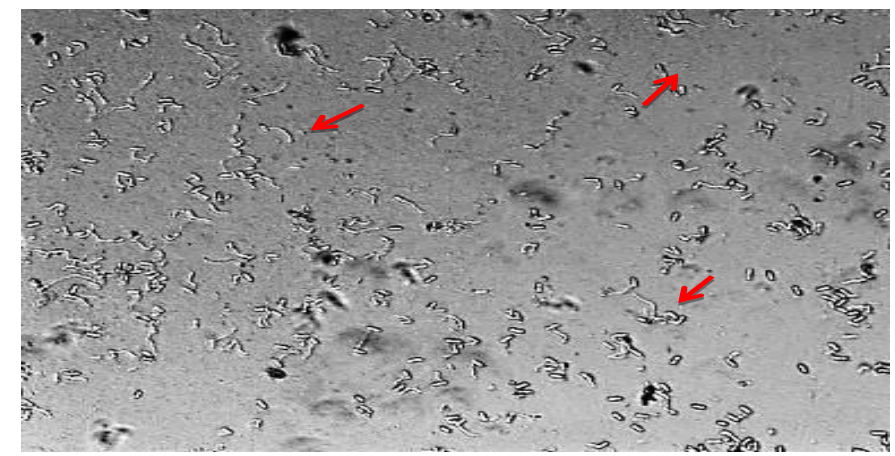

Plate 18. Small germ tubes of C. gloeosporioidesafter 8 hours at $25^{\circ} \mathrm{C}$

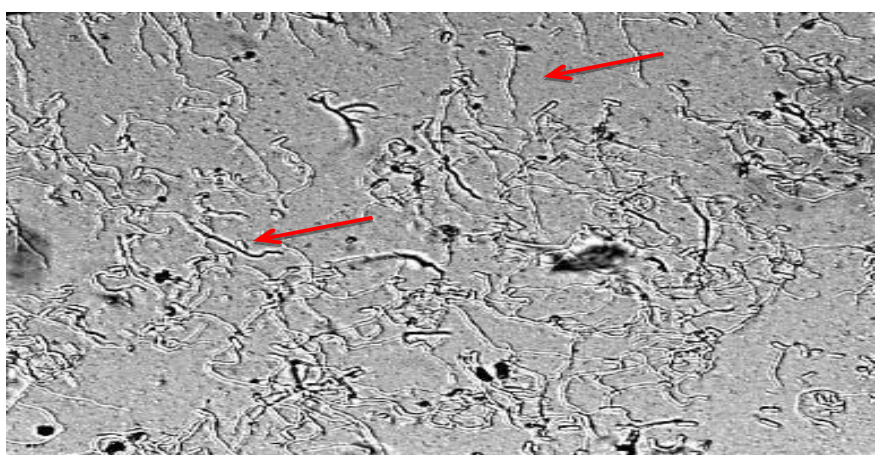

Plate 19. Long thread like germ tubes C. gloeosporioidesafter 24 hours at $25^{\circ} \mathrm{C}$ 


\section{Symptom on green fruits}

The disease initiated as expression of pinhead spots during the first fortnight of January, which gradually enlarge to attain size of 5.7$6.2 \mathrm{~mm}$ in diameter. The spots were brown to tan, sunken, circular and have minute black stromata in the center which produced spore masses in wet weather.

Several spots coalesce to form bigger lesions. The infected area become corky, hard and often develop cracks in severe infection (Plate 3 \& 4). The results were in similarly with Tandon and Singh (1969).

\section{Symptom on mature fruits}

The infection on ripe fruits started as light to dark brown and black small depressed and water soaked lesions which later become soft, sunken and causing browning of tissues (Plate $5 \& 6)$.

The size of lesions varied from 7- $8.5 \mathrm{~mm}$ in diameter. After few days, entire fruit is rotten. Similarly, Tandon and Singh (1969) found softening of tissues occurs on mature fruits and lesions attain 10- $20 \mathrm{~mm}$ size. Mertely et al (2005) also reported that lesions on ripening fruits become brown that expand to slightly sunken.

\section{Expression of Rhizopus rot symptom}

The symptoms of Rhizopus rot were only observed on ripe fruits. Earlier, fruit surface was soft and secrete red juice from fruit tissues but later on got rotten. One day afterward, white fuzzy mycelium appeared on fruit. Tiny black spherical structures appeared at end of mycelium (Plate $7 \& 8$ ). Similar symptom expression of Rhizopus rot was also recorded by Bolda (2012) while working on strawberry diseases.

\section{Isolation and identification of the causal} agent

During isolation from the different infected parts of the strawberry two types of pathogen, Colletotrichum gloeosporioides and Rhizophus rot were found responsible for causing leaf blight and fruit rot symptom in strawberry. The majority of the isolation yielded Colletotrichum gloeosporioides, therefore the detail laboratory studies was only carried out on this pathogen.

\section{Characteristics of Colletotrichum}

Hyphae of the isolated causal agent were septate, hyaline with several oil drops, initially cottony white and become grey in later stages (Plate 9). The present observations were in similarity with Hiremath et al (1993) and Ivanovic et al (2007). Conidia were cylindrical or oblong, straight with rounded ends, non-septate with oil droplets and were identical to those present on leaves and fruits (Plate 10). The conidia measured $12.9-16.9 \mu \mathrm{m} \times 3.01-4.5 \mu \mathrm{m}$ at $45 \mathrm{x}$ and $307.67-310.61 \mu \mathrm{m} \times 103.77 \mu \mathrm{m}$ at $100 \mathrm{x}$ microscopic area (Plate 11\&12). Freeman et al (1998) also recorded similar size and shape of conidia of Colletotrichum gloeosporioides causing diseases of various fruits. Acervulli were not produced inside the culture but were present inside the leaf tissues. Similar findings were also reported by Smith and Black (1990) while working on Colletotrichum species causing strawberry diseases. Acervulli were round to irregular in shape, creamy in color with dark brown to black erect setae measuring $2.85 \mu \mathrm{m}-10.52$ $\mu \mathrm{m}$ (Plate $13 \&$ \& 14). The mycelium of growing culture is hyaline, septate and branched. Freeman et al (1998) also reported similar findings. On the basis cultural and morphological characteristics and identification report of Indian Type Culture Collection (ITCC), Division of Plant 
Pathology, Indian Agricultural Research Institute, New Delhi, the causal agent of producing anthracnose type symptom was identified as Colletotrichum gloeosporioides.

\section{Characteristics of Rhizopus}

The fungus has coenocytic hyphae, rhizoids, stolon, erect sporangiophores and globose, black sporangia, 90-180 $\mu \mathrm{m}$ in diameter (Plate $15 \& 16)$. Colonies on PDA were whitecottony in color. Sporangiophores were light brown and 10-12 $\mu \mathrm{m}$ in diameter. Sporangiospores were globose to oval and brown in color. On the basis cultural and morphological characteristics, the causal agent ripe fruit was identified as Rhizopus rot of strawberry. The findings were in accordance with Kwon et al (2014).

\section{Pathogenecity test}

The data in Table 1 showed that pin prick method of inoculation produced symptoms on leaves, green fruits and mature fruits after 4,5 and 3 days where as it was 5, 6 and 3 days in spray method of inoculation, respectively. On leaves and green fruits, symptoms developed one day earlier in pin prick method than spray method. On leaves brown to black necrotic spots having ashy grey center and dark brown margins were produced. On green fruits black pinhead corky spots and on mature fruits brown water soaked spots were produced. The per cent lesion formation was also recorded more in pin prick method on leaves, green fruit and mature fruit (80\%) as compared to spray method $(50 \%)$ of inoculation.

On mature fruit, cent per cent inoculation success was achieved by pin prick method as compared to spray method of inoculation. The development of average lesion size on leaves, green fruits and mature fruits were also bigger $(6,6.2$ and $8.5 \mathrm{~mm})$ by pin prick as compared to spray method of inoculation $(5.2,5.7$ and $7.0 \mathrm{~mm}$ ), respectively. These findings are in accordance with Singh (2006) who reported that injured leaves, unripe and ripe fruits of guava were more susceptible for disease development than uninjured leaves and fruits. In unripe injured fruits, symptoms were developed earlier (3 days) as compared to uninjured fruits (4 days). Similarly, on ripe fruits, injured fruits induced symptoms after 2 days but uninjured induced after 3 days and on injured leaves symptoms appeared after 5 days but on uninjured leaves symptoms did not appeared. Similarly, pathogenecity test of Rhizopus rot of strawberry produced white fuzzy mycelium on the rotten fruits. Similarly, Kwon et al (2014) reported that white mycelium grew from the primary infection site and gradually covered the fruit with tufted whisker-like grey sporangiophores and sporangia.

\section{Effect of temperature regimes on mycelial growth of $C$. gloeosporioides}

The growth of the fungus $(1.24 \mathrm{~cm})$ started after 24 hours of inoculation at $25^{\circ} \mathrm{C}$ and 50 per cent area covered after 96 hours of inoculation (Table 2). A temperature of $25^{\circ} \mathrm{C}$ was found significantly effective in favoring the growth of the fungus $(4.32 \mathrm{~cm}$ after 96 hours and $8.92 \mathrm{~mm}$ after 216 hours) as compared to other temperatures. The second best temperature was $30^{\circ} \mathrm{C}$ where $3.60 \mathrm{~mm}$ growth of mycelium was recorded after 96 hours of inoculation. Minimum growth was recorded at temperature $15^{\circ} \mathrm{C}$ and no growth was achieved at $5^{\circ} \mathrm{C}$. In general, temperature between $25-30^{\circ} \mathrm{C}$ found ideal for mycelial growth and below $15^{\circ} \mathrm{C}$ failed to support the growth of pathogen. Similarly, Rahman et al (2003) reported temperature of $28-30^{\circ} \mathrm{C}$ was the most suitable for the growth of $C$. gloeosporioides. Srivastava and Tandon (1969) also reported $25^{\circ} \mathrm{C}$ was optimum temperature for growth of the fungus. The present findings were also in agreement with Leandro et al (2003) and Forcelini (2013). 
Effect of temperatures regimes on sporulation

The data presented in Table 3 reveal that the highest sporulation $\left(32.20 \times 10^{4}\right.$ spore $\left./ \mathrm{ml}\right)$ occurred at $25^{\circ} \mathrm{C}$ temperature in 15 days old culture which was significantly more than $30^{\circ} \mathrm{C}\left(27 \times 10^{4}\right.$ spore $\left./ \mathrm{ml}\right)$ and $20^{\circ} \mathrm{C}(24.4 \times$ $10^{4}$ spore $/ \mathrm{ml}$ ). These findings are in accordance with Singh (2006) who reported highest sporulation $\left(34.50 \times 10^{4}\right.$ spores $\left./ \mathrm{ml}\right)$ of guava anthracnose $(C$. gloeosporioides) at $25^{\circ} \mathrm{C}$ followed by $30^{\circ} \mathrm{C}\left(26.30 \times 10^{4}\right.$ spore $/ \mathrm{ml}$ ). Kumara and Rawal (2008) also noticed maximum growth and sporulation of papaya anthracnose $(C$. gloeosporioides $)$ between $28^{\circ} \mathrm{C}$ to $30^{\circ} \mathrm{C}$.

\section{Effect of temperatures regimes on sporulation}

The data presented in Table 3 reveal that the highest sporulation $\left(32.20 \times 10^{4}\right.$ spore $\left./ \mathrm{ml}\right)$ occurred at $25^{\circ} \mathrm{C}$ temperature in 15 days old culture which was significantly more than $30^{\circ} \mathrm{C}\left(27 \times 10^{4}\right.$ spore $\left./ \mathrm{ml}\right)$ and $20^{\circ} \mathrm{C}(24.4 \times$ $10^{4}$ spore $/ \mathrm{ml}$ ). These findings are in accordance with Singh (2006) who reported highest sporulation $\left(34.50 \times 10^{4}\right.$ spores $\left./ \mathrm{ml}\right)$ of guava anthracnose $(C$. gloeosporioides) at $25^{\circ} \mathrm{C}$ followed by $30^{\circ} \mathrm{C}\left(26.30 \times 10^{4}\right.$ spore $/ \mathrm{ml}$ ). Kumara and Rawal (2008) also noticed maximum growth and sporulation of papaya anthracnose (C. gloeosporioides) between $28^{\circ} \mathrm{C}$ to $30^{\circ} \mathrm{C}$.

\section{Effect of temperature regimes on spore germination}

Significant spore germination (22.4\%) was recorded at $25^{\circ} \mathrm{C}$ temperature after 4 hours of incubation as compared to other temperatures and incubation where no germination was recorded (Table 4). Germ tube usually emerged from the round end of spores but sometimes also from both ends (Plate $17 \&$
18).Significantly cent per cent spore germination was observed at $25^{\circ} \mathrm{C}$ and $30^{\circ} \mathrm{C}$ after 16 hours of incubation as compared to 5 , 15 and $20^{\circ} \mathrm{C}$ temperatures. The spores completely failed to germinate at $5^{\circ} \mathrm{C}$ even after 24 hours of incubation. In general, temperature between 25 to $30^{\circ} \mathrm{C}$ was more favorable for spore germination and below $20^{\circ} \mathrm{C}$ was unfavorable. Similarly, Sattar and Malik (1939) also observed $25^{\circ} \mathrm{C}$ as optimum temperature for spore germination of $C$. gloeosporioides. The results were also in similarity with Dodd et al (1991) and Hubballia et al (2011).

\section{References}

Anonymous http//www.indiastat.com/Area and Production of Strawberry in India.

Bolda, M., 2012. Rhizopus and Mucor rot in strawberry. Canebarries Production Manual. UC ANR Publication.

Dodd, J. C., A. B. Estrada, J. Matcham, P. Jeffereries, and Jeger, M. J. 1991. The effect of climatic factors on Colletotrichum gloeosporioides, causal agent of mango anthracnose, in the Philippines. Plant Pathol 40: 568-75.

Forcelini, B. B. 2013. Effect of inoculum concentration, temperature and wetness duration on fruit rot development on different strawberry cultivar. M.Sc. thesis, Graduate School, University of Florida, USA.

Freeman, S., T. Katan, and Shabi, E.1998. Characterization of Colletotrichum species responsible for anthracnose diseases of various fruits. Pl. Dis. 82: 596-605.

Heidenreich, C., and Turechek, B.2013.Strawberry leaf spot. Can. J. Plant Pathol. 16:177-86.

Howard, C.M., J.L. Maas, C.K. Chandler and Albregts, E.E.1992. Anthracnose of strawberry caused by the Colletotrichum complex in Florida. Plant Dis. 76: 976-81.

Hubballia, M., S. Nakkeerana, T. 
Raguchandera, T. Ananda and Renukadevi, P.2011. Physiological characterisation of Colletotrichum gloeosporioides, the incidence of anthracnose disease of noni in India. Arch. Phytopathol. Pl. Prot. 44: 1105-14.

Ivanovic, M. S., B. B. Duduk, M. M. Ivanovic, and Ivanovic, M. S.2007. Anthracnose- a new strawberry disease in Serbia and its control by fungicides. Proc. Nat. Sci. 113: 71-81.

Jefferies, P., J. C. Dodd, M. J. Jeger, and Plumbley, R. A.1990.The biology and control of Colletotrichum species on tropical fruit crops. Plant Pathol. 39: 34366.

Kaur, S., and Thind S. K. 2016. Epidemiology of strawberry anthracnose (Colletotrichum gloeo,sporioides) in Punjab: An agrometeorological approach. Pl. Dis. Res. 31 (2): 154-157.

Kumara, K., and Rawal, R. D.2008. Anthracnose disease of papaya. Trop. Agri. Res. Ext. Pp: 1-12.

Kwon, H. D., W. Kang, H. S. Yoon, Y. S. Kwak, and Kim, J. 2014. Rhizopus fruit rot caused by Rhizopus oryzae on strawberry. J. Agric. Life Sci. 48: 27-34.

Leandro, L. F. S., M. L.Gleason, F. W. Nutter, J.R. Wegulo, and Dixon P M (2003) Influence of temperature and wetness duration on conidia and appressoria of Colletotrichum acutatum on symptomless strawberry leaves. Phytopathol. 93: 51320.

Legard, D. E., and Mackenzie, S. J. 2003. Evaluation of fungicides to control anthracnose fruit rot of strawberry.University of Florida, Dover, Florida.
Mertely, J. C., N. A. Peres, and Chandler, C. K. 2005. Anthracnose fruit rot of strawberry. University of Florida, Gainesville, FL. Pp: 207.

Rahman, N., M. Carnes, J. Driver, and Louws, F. J. 2009. Fungicidal control of anthracnose fruit rot in strawberry cultivar Chandler in North Carolina. Plant Dis. 4: 32

Sattar, A., and Mallik, S. A.1939. Some studies on anthracnose of mango caused by Glomerella cingulata (Stonem) Spauld Sch. (Colletotrichum gloeosporioides) Penz. Ind. J. Agric. Sci. 1: 511-21.

Singh, A. 2006. Epidemiology and management of guava anthracnose. Ph. D. dissertation. Punjab Agricultural University, Ludhiana, India.

Smith, B. J. 2008.Epidemiology and Pathology of Strawberry Anthracnose: A North American Perspective. HortSci. 43: 6973.

Smith, B. J. and Black, L. L. 1990. Morphological, cultural, and pathogenic variation among Colletotrichum species isolated from strawberry. Plant Dis. 74: 69-76.

Srivastava, M. P. and Tandon, R. N.1969. Post harvest diseases of guava in India. $\mathrm{Pl} \mathrm{Dis}$ Reptr 53 (3): 206-208. Tandon I N and Singh B B (1969) Studies on anthracnose of guave and its control. Indian Phytopath 22: 322-26.

Vidyalakshni, A. and Divya, C.V. 2013.New report of Colletotrichum gloeosporioides causing anthracnose of Pisonia alba in India. Arch.Phytopathol. Pl. Prot. 46: 201-04.

\section{How to cite this article:}

Thind, S. K., Simranjit Kaur and Ishwinder Kamboj. 2020. Symptomatology and Pathology of Strawberry Diseases Causing Leaf Blight and Fruit Rot in Punjab. Int.J.Curr.Microbiol.App.Sci. 9(07): 4035-4045. doi: https://doi.org/10.20546/ijcmas.2020.907.473 